\title{
A INICIATIVA DO CINTURÃO E ROTA E OS DILEMAS DA AMÉRICA LATINA
}

\author{
Diego Pautasso ${ }^{1}$ \\ Tiago Soares Nogara² \\ Carlos Renato Ungaretti ${ }^{3}$ \\ Gaio Doria ${ }^{4}$
}

\begin{abstract}
Este artigo visa discutir o papel da extensão da Nova Rota da Seda - ou Iniciativa do Cinturão e Rota (Belt and Road Initiative - BRI) - para a América Latina em um quadro de transição sistêmica. Argumentamos que, diante das dificuldades de articulação de soluções locais para os dilemas regionais, a oportunidade de adensamento das relações e da cooperação com a China tende a suprir lacunas necessárias para fazer avançar projetos de desenvolvimento dos países da região. Após a introdução, na segunda seção, trataremos do processo de ascensão internacional da China, reconhecendo a Nova Rota da Seda como vetor fundamental de sua projeção global. $\mathrm{Na}$ terceira seção, abordaremos o panorama de crescente sinergia entre os países da América Latina e a China, bem como as possibilidades esboçadas pela possível implementação da Nova Rota da Seda na região. Por fim, na quarta seção, discutiremos os dilemas latino-americanos nesse complexo quadro de transição sistêmica, abordando as conexões entre o recrudescimento da rivalidade sino-estadunidense e as questões pertinentes aos mecanismos de cooperação bilateral e multilateral hemisféricos.
\end{abstract}

Palavras-chave: Iniciativa do Cinturão e Rota; Rota da Seda; América Latina; China; integração regional.

\section{THE BELT AND ROAD INITIATIVE AND THE DILEMMAS OF LATIN AMERICA}

The article aims to discuss the role of New Silk Road's extension - or Belt and Road Initiative (BRI) - to Latin America in a framework of systemic transition. We argue that, given the difficulties in articulating solutions to regional dilemmas, the opportunity to strengthen relations and cooperation with China tends to fill the necessary gaps to advance infrastructure integration projects in the Latin America's countries. In the first section, we will discuss China's international rise process, recognizing the New Silk Road as a fundamental vector of its global projection. In the second section, we will address the panorama of growing synergy between Latin American countries and China, as well as the opportunities outlined by the possible implementation of the New Silk Road in the region. Finally, in the last section, we will discuss Latin American dilemmas in this complex systemic transition framework, addressing the connections between the resurgence of Sino-US rivalry and the pertinent issues of bilateral and multilateral hemispheric cooperation mechanisms.

Keywords: Belt and Road Initiative; Silk Road; Latin America; China; regional integration.

1. Professor do Colégio Militar de Porto Alegre (CMPA); e doutor em ciência política pela Universidade Federal do Rio Grande do Sul (UFRGS). E-mail: <dgpautasso@gmail.com>. Orcid: <https://orcid.org/0000-0002-2393-1903>.

2. Doutorando em ciência política na Universidade de São Paulo (USP); e mestre em relações internacionais pela Universidade de Brasília (UnB).E-mail: <tiagosnogara@gmail.com>. Orcid: <https://orcid.org/0000-0003-1560-8150>.

3. Mestrando no Programa de Pós-Graduação em Estudos Estratégicos Internacionais (PPGEEI)/UFRGS. E-mail: <renato.ungaretti94@gmail.com>. Orcid: <https://orcid.org/0000-0002-1599-2941>.

4. Doutor em direito e mestre em economia chinesa pela Renmin University of China.E-mail: <gaiodoria@gmail.com>. Orcid: <https://orcid.org/0000-0002-3936-7622>. 


\section{LA INICIATIVA DE LA FRANJA Y LA RUTA Y LOS DILEMAS DE AMÉRICA LATINA}

El artículo tiene como objetivo discutir el papel de la extensión de la Nueva Ruta de la Seda - 0 Iniciativa de la Franja y la Ruta (Belt and Road Initiative - BRI) - a América Latina en un marco de transición sistémica. Argumentamos que, dadas las dificultades para articular soluciones locales a los dilemas regionales, la oportunidad de fortalecer las relaciones y la cooperación con China tiende a llenar los vacíos necesarios para impulsar proyectos de desarrollo en los países de la región. En el primer apartado nos ocuparemos del proceso de ascensión internacional de China, reconociendo la Nueva Ruta de la Seda como vector fundamental de su proyección global. En la segunda parte, abordaremos el panorama de sinergia creciente entre los países de América Latina y China, así como las posibilidades trazadas por la posible implementación de la Nueva Ruta de la Seda en la región. Finalmente, en la última sección, discutiremos los dilemas latinoamericanos en este complejo panorama de transición sistémica, abordando las conexiones entre el resurgimiento de la rivalidad chino-estadounidense y los temas pertinentes a los mecanismos hemisféricos de cooperación bilateral y multilateral.

Palabras clave: Iniciativa de la Franja y la Ruta; Ruta de la Seda; América Latina; China; integración regional.

JEL: F50.

DOl: http://dx.doi.org/10.38116/rtm24art3

Data de envio do artigo: 31/8/2020. Data de aceite: 3/11/2020.

\section{INTRODUÇÃO}

Os tempos de transição sistêmica (Arrighi, 2008) costumam acirrar o nível de tensão das disputas políticas, bem como acelerar a ascensão de forças disruptivas. A ocorrência desses cenários atualiza e aumenta a complexidade dos desafios a serem enfrentados pelos Estados nacionais, e, obviamente, os países latino-americanos não escapam a tais dinâmicas. Ao mesmo tempo que o epicentro geoeconômico se desloca do Atlântico Norte para a Bacia do Pacífico, a América Latina tem apresentado enormes dificuldades no que diz respeito às dinâmicas de crescimento em escala global.

Ainda em 2019, em um contexto anterior aos acontecimentos pertinentes à pandemia do coronavírus, a Comissão Econômica para a América Latina e o Caribe (CEPAL) já previa que o período de 2014 a 2020 registraria o menor avanço econômico da região nos últimos setenta anos, com queda de $4 \%$ na renda per capita. ${ }^{5}$ Constatados os efeitos da pandemia, projeçóes estimam que o encolhimento será de 3,8\% em 2020, dado pior do que o das retraçóes ocorridas durante as crises financeira de 2009 (2,1\%) e da dívida externa em 1983 (2,4\%). Paralelamente, uma série de sobressaltos e crises políticas implicou o esvaziamento de mecanismos multilaterais de cooperação propriamente regionais, sobretudo da

5. Ver previsão da CEPAL em América Latina... (2019).

6. Ver previsão do Goldman Sachs em Goldman... (2020). 
Comunidade de Estados Latino-Americanos e Caribenhos (CELAC) e da União de Naçōes Sul-Americanas (UNASUL).

Apesar dos percalços e tensóes dele decorrentes, o panorama de recrudescimento da rivalidade sino-estadunidense, no entanto, pode vir a afetar positivamente as dinâmicas regionais. Nesse sentido, este artigo visa discutir o papel da extensão da Nova Rota da Seda - ou Iniciativa do Cinturão e Rota (Belt and Road Initiative - BRI) - para a América Latina em um quadro de transição sistêmica. Argumentamos que, diante das dificuldades de articulação de soluções autóctones para os dilemas regionais, a oportunidade de adensamento das relaçóes e da cooperação com a China tende a suprir lacunas necessárias para fazer avançar projetos de integração de infraestrutura e desenvolvimento dos países da região.

A nosso ver, essa hipótese ganha força em razão do enfraquecimento dos mecanismos de cooperação multilateral regional e da incapacidade relativa dos Estados Unidos, principal potência hemisférica, em fornecer soluções para as demandas locais. Ou seja, apesar do giro político-ideológico de uma série de governos da regiáo ter enfraquecido o anterior ciclo de regionalismo pós-liberal, Pequim segue sendo alternativa capaz de prover a demanda tanto por mercados para as commodities quanto por possíveis investimentos em infraestrutura (de transporte, energia e comunicação), contribuindo para a superação de um gargalo histórico dos processos de integração subcontinental. Além disso, o quadro de competição entre Estados Unidos e China na região amplia as possibilidades de barganha para as políticas exteriores dos países latino-americanos, revertendo um quadro de limitaçóes das margens de manobra internacionais persistente desde os tempos da Guerra Fria.

Cabe destacar que a análise não se propóe ao exame qualitativo do padrão do relacionamento da China com os países latino-americanos, mas da forma como a ascensão da BRI tende a convergir com a histórica necessidade de superação dos hiatos de integração de infraestrutura que marcam a região. Ainda assim, ressaltamos nossa explícita contrariedade às teses que designam a maior presença econômica chinesa em países periféricos como exemplo de um neocolonialismo ou neoimperialismo, na medida em que tais escritos invariavelmente confundem relaçóes assimétricas com relaçôes de dominação. Expusemos nossos argumentos sobre tal polêmica em Nogara (2020) e Pautasso et al. (2020).

Com efeito, de modo a dar conta do tema em questão, na segunda seçáo trataremos do processo de ascensão internacional da China, reconhecendo a Nova Rota da Seda como vetor fundamental de sua projeçáo global. Na terceira seçáo, abordaremos o panorama de crescente sinergia entre os países da América Latina e a China, bem como as possibilidades esboçadas pela possível implementação da Nova Rota da Seda na região. Por fim, na quarta seção, discutiremos os dilemas 
latino-americanos nesse complexo quadro de transição sistêmica, abordando as conexóes entre o recrudescimento da rivalidade sino-estadunidense e as questóes pertinentes aos mecanismos de cooperação bilateral e multilateral hemisféricos.

\section{A ASCENSÃO INTERNACIONAL CHINESA E A NOVA ROTA DA SEDA}

O constante e notável crescimento econômico chinês das últimas décadas vem sendo acompanhado da manutenção da liderança do partido comunista no país, o mesmo responsável por dirigir a Revolução de 1949. Mais do que uma vitória dos comunistas chineses, a revolução representou um legítimo processo de reconstrução nacional, na medida em que pôs fim à submissão política às potências (Grã-Bretanha, França, Japão etc.), cuja atuação teve como resultado o chamado século das humilhaçóes, assim conhecido pelas invasóes e chantagens estrangeiras que resultaram na desarticulação completa da civilização chinesa. Sob a condução de Mao Tsé-Tung, os chineses garantiram a integridade do território nacional, a superação de décadas de guerra civil, a restauração da soberania para um país que estava à beira da fragmentação, bem como a retomada de um processo de desenvolvimento econômico.

Uma segunda geração de lideranças, tendo Deng Xiaoping como membro destacado, implementou as diretrizes de reforma e abertura, apresentando uma reorganização das prioridades nacionais, a partir da terceira plenária do $11^{\circ}$ Comitê Central do Partido Comunista da China, ocorrida em 1978 (Kissinger, 2011). Embora tenha sido uma estratégia de abertura econômica sem abertura política, contrastando com as escolhas soviéticas, a China promoveu profundos ajustes institucionais. Assim, a correção de rumos da modernização socialista incluiu uma reorientação da inserção internacional do país asiático, como forma de atrair investimentos e tecnologias, abrir mercados e também se integrar, progressivamente, às instituiçóes multilaterais de âmbito regional e global. Essa movimentação contribuiu para a superação do relativo isolamento político em favor de maior engajamento e integração ao sistema internacional.

Nesse sentido, a atuação da China tem buscado reformar as estruturas hegemônicas de poder forjadas no pós-guerra sob a liderança de Washington, tais como o Fundo Monetário Internacional (FMI), o Banco Mundial e a Organização Mundial do Comércio (OMC). Simultaneamente, Pequim tem promovido mecanismos alternativos ao domínio ocidental, tais como: o Novo Banco de Desenvolvimento (NBD), operado por Brasil, Rússia, Índia, China e África do Sul (BRICS), e o Banco Asiático de Investimento em Infraestrutura (Asian Infrastructure Investment Bank - AIIB); o Sistema de Pagamento Internacional da China, alternativo à Sociedade para Telecomunicaçóes Financeiras Interbancárias Mundiais (Society for Worldwide Interbank Financial 
Telecommunication - SWIFT); o China UnionPay, rival das bandeiras Visa e Master; e o Centro de Avaliação de Crédito Universal, que antagoniza a Moody's e a Standard and Poor's. Além disso, o governo chinês tem impulsionado instrumentos multilaterais de concertação política e cooperação, como a Parceria Econômica Abrangente Regional, o BRICS, a Organização para a Cooperação de Xangai (OCX), o Fórum de Boao para a Ásia e, sobretudo, a Nova Rota da Seda (Stuenkel, 2018, p. 130-131).

A diplomacia chinesa também se mostra assertiva no fomento às relaçóes bilaterais, uma vez que estas surgem como alternativas às dificuldades encontradas no exercício de liderança e defesa do interesse nacional nos espaços de caráter multilateral (Shambaugh, 2013). Diante dos empecilhos multilaterais, o perfil de implementação da Nova Rota da Seda atua visando explorar linhas de menor resistência, pois as necessidades infraestruturais de países periféricos são explícitas, e a China detém notáveis capacidades de financiamento e expertise em engenharia e produção de insumos e máquinas. Ou seja, o fomento às obras de infraestrutura viabiliza fluxos comerciais e fortalece o efeito gravitacional da economia chinesa, contribuindo para a recriação de um sistema sinocêntrico. Por isso, observa-se a adequação discursiva do Partido Comunista da China (PCCh): se até o começo do século XXI a retórica centrava-se em ideias-força voltadas ao desenvolvimento nacional, a partir do século XXI apareceram os conceitos de going global, Chinese dream e mundo harmonioso, entre outros, refletindo a projeção em escala global.

A ideia-força que estrutura o atual paradigma de inserção internacional chinesa reside, indubitavelmente, nos esforços em prol da implementaçẫo da BRI, ou Nova Rota da Seda, lançada em 2013 pelo presidente Xi Jinping. Com precedentes importantes no modelo de relaçôes sino-angolanas, depois expandido para o restante da África, o intercâmbio baseado na implementação de obras de infraestrutura e na operacionalização do fornecimento de recursos naturais serviu para emular outros mecanismos de cooperação. A Nova Rota da Seda, nesse sentido, é fruto do amadurecimento dos projetos de cooperação ensejados pela estratégia de inserção internacional chinesa - cujo ponto de partida perpassa a capacidade de execução e investimento em significativas obras de infraestrutura-, que adquire níveis de complexidade cada vez maiores, abrangendo questóes de governança, sustentabilidade e outras áreas do desenvolvimento social.

Em março de 2015, foi elaborado um plano de ação por meio do trabalho conjunto de três agências governamentais - Ministério de Relaçóes Exteriores, Ministério do Comércio e Comissão Nacional de Reforma e Desenvolvimento (CNRD) - com a finalidade de delinear os princípios e os marcos norteadores da criaçáo dos eixos da Nova Rota da Seda. Segundo o documento, o projeto perpassaria a Ásia, a Europa e a África, conectando o vibrante eixo econômico 
da Ásia Oriental com a Europa. O Cinturão Econômico teria como foco o estabelecimento das seguintes conexões: entre a China, a Ásia Central, a Rússia e a Europa; entre a China, o Golfo Pérsico e o mar Mediterrâneo; e entre a China e o Sudeste Asiático, a Ásia Meridional e o oceano Índico. A Rota da Seda Marítima foi projetada visando articular a costa chinesa em direção à Europa, perpassando o Mar do Sul da China e o oceano Índico, além do sul do Pacífico, também através do Mar do Sul da China (NDRC, 2015).

Em consonância com tais movimentaçōes, Yiwei (2016) argumenta que a iniciativa possui moldes contrastantes com aqueles do processo tradicional de globalização, na medida em que a sua proposta possui o potencial de proporcionar uma globalização inclusiva, sem assimetrias entre o marítimo e o terrestre, o urbano e o rural, os países desenvolvidos e os em desenvolvimento. A inserção e a inclusão estariam centradas no que o autor denominou cinco fatores de conectividade, nomeadamente: i) comunicação política; ii) conectividade de infraestrutura; iii) comércio desimpedido; iv) circulação monetária; e v) entendimento entre pessoas. No que diz respeito à comunicação política, percebe-se que a República Popular da China se encontra em um processo de estabelecimento de "parcerias estratégicas" no plano externo, sobretudo com países associados ao cinturão e à rota marítima (Zhang, 2015; Yiwei, 2016).

A interligação da China com a Europa, integrando a Eurásia, passa pela execução de projetos estratégicos, tais como a modernização do porto de Piraeus na Grécia e e construção de uma ferrovia entre a Hungria e a Sérvia. Em linhas gerais, Yiwei (2016, p. 66) defende que a Grécia e a Polônia representam importantes pontos de passagem para a China acessar a Europa, ao passo que os quadros institucionais do $16+1$ possibilitam um maior envolvimento político com os países da Europa Oriental e Central. ${ }^{8}$ As estratégicas relaçóes com a Alemanha também são de enorme relevância para o êxito da iniciativa, já que o país representa o ponto final da ferrovia que liga Chongqing, Xinjiang e Duisburgo. A cidade alemã é a porta de entrada de trens que integram a BRI na Europa, constituindo o centro de distribuiçáo para o restante da União Europeia (UE). Mesmo com a pandemia, houve um recente incremento dos trens que chegam da China, retratando também uma tendência que se verificou desde 2016, que é a brutal interdependência entre a China e a principal economia europeia (Carbajosa, 2020).

Finalmente, é importante frisar que a cooperação entre China e Europa, além de ilustrada no fato de que a UE é o principal destino das exportaçóes chinesas e de

7. Em 2016, a China Ocean Shipping Company (COSCO) adquiriu a participação majoritária do porto e assumiu formalmente sua gestão e operação. 0 Porto de Piraeus se transformou no maior porto do Mediterrâneo e em um dos terminais de contêineres que crescem mais rapidamente no mundo (Xi..., 2019).

8. Posteriormente, 0 agrupamento foi expandido para 17+1, com o ingresso da Grécia. 
que a China é o segundo principal importador de produtos do bloco, ${ }^{9}$ presenciou consideráveis avanços nos últimos anos, como sugere comunicado conjunto entre a China e a UE em $2019^{10}$ e as articulaçóes orientadas à cooperação entre o Fundo da Nova Rota da Seda e o Fundo Europeu de Investimento (European Investment Fund - EIF). Não são poucos os acordos e as parcerias firmadas recentemente com os países que estão no escopo da Nova Rota da Seda. Até março de 2020, já eram 138 os países que assinaram algum formato de memorando de entendimento ou acordo bilateral sinalizando a intenção de participar da BRI. ${ }^{11}$

No intuito de institucionalizar a iniciativa e aprofundar a concertação multilateral, a China sediou o primeiro Belt and Road Forum for International Cooperation (BRF) em 2017, em Pequim, contando com a presença de trinta líderes mundiais e representantes oficiais de mais de trinta governos. ${ }^{12}$ No discurso de abertura, o presidente Xi Jinping reiterou os princípios da BRI e ressaltou os avanços durante o período de 2013 a 2017, sublinhando o aprofundamento da cooperação em matéria de diplomacia, cultura, comércio, finanças e infraestrutura. ${ }^{13} \mathrm{O}$ presidente chinês ainda defendeu que a iniciativa se constitua como um caminho para a paz, prosperidade, abertura, inovação e conexão entre diferentes civilizaçóes. No comunicado conjunto da mesa redonda de líderes do $\mathrm{BRF}^{14}$ os líderes mundiais, bem como os representantes de organizaçóes multilaterais, ${ }^{15}$ reforçaram os princípios, objetivos e medidas de cooperação internacional que fundamentam a iniciativa.

Em abril de 2019, a China sediou o segundo BRF, também em Pequim, desta vez com a participação de quarenta líderes mundiais e uma série de representantes de organizaçóes multilaterais. No comunicado conjunto da mesa redonda de líderes do segundo BRF, os líderes mundiais e representantes das organizaçóes realçaram o fortalecimento da sinergia política para o desenvolvimento, o incremento da conectividade em infraestrutura, a promoção do desenvolvimento sustentável, o fortalecimento da cooperação prática e a promoção de intercâmbios culturais. ${ }^{16}$ No anexo do referido comunicado, foram listados os corredores econômicos

9. 0 comércio bilateral entre UE e China supera, em média, o montante de $€ 1$ bilhão por dia. Disponível em: <https:// bit.ly/3u55YTH>.

10. Disponivel em: <https://bit.ly/2ZsOMLp>.

11. Dos 138 países: 38 são da África Subsaariana; 34, da Europa e Ásia Central; 25, do Pacífico e Leste Asiático; 17, do Oriente Médio e Norte da África; 18, da América Latina; e 6, do Sudeste Asiático. Disponível em: <https://en.imsilkroad. com/p/314398.html>.

12. Cabe mencionar a presença de dois presidentes sul-americanos, Mauricio Macri (Argentina) e Michelle Bachelet (Chile).

13. Disponivel em: <http://2017.beltandroadforum.org/english/n100/2018/0306/c25-1038.html>.

14. Disponivel em: <http://2017.beltandroadforum.org/english/n100/2017/0516/c22-423.html>.

15. Participaram do fórum o secretário-geral da Organização das Nações Unidas (ONU), António Guterres, o presidente do Banco Mundial, Yong Kim, e a diretora do FMI, Christine Lagarde.

16. Disponível em: <http://www.beltandroadforum.org/english/n100/2019/0427/c36-1311.html>. 
e projetos catalisados pela iniciativa, ${ }^{17}$ as plataformas setoriais de cooperação multilateral, ${ }^{18}$ assim como outros esforços relevantes trazidos pelos participantes.

Desde 2013, já são mais de US\$ 755 bilhóes em investimentos dos países que aderiram formalmente à iniciativa chinesa. Entre 2014 e 2019, a combinação de investimento estrangeiro direto (IED) e contratos de construção somou, invariavelmente, mais de US\$ 100 bilhôes anuais, chegando ao pico de US\$ 127,47 bilhóes em 2015 (gráfico 1). Cabe salientar que nem todos os investimentos e projetos encontram-se diretamente associados à BRI, tendo em vista que parte ocorreu antes mesmo dos países ingressarem formalmente na iniciativa. Mesmo assim, não se pode ignorar que, desde o seu lançamento, a BRI tem impulsionado ainda mais os investimentos externos chineses, intensificando a estratégia going global delineada no início deste século e revelando, de forma mais nítida, a lógica de Estado que impera na internacionalização econômica chinesa (Rodrigues e Hendler, 2018). Ainda mais interessante do que a China ter ultrapassado os Estados Unidos no relatório de 2019 da Fortune - com 124 empresas entre as quinhentas maiores do mundo, contra 121 estadunidenses - é o fato de $73 \%$ das empresas chinesas ali listadas serem públicas governamentais, revelando o enlace entre Estado e corporaçóes.

GRÁFICO 1

Investimentos chineses e contratos de construção em países da BRI (2013-2020) (Em US\$ bilhões)

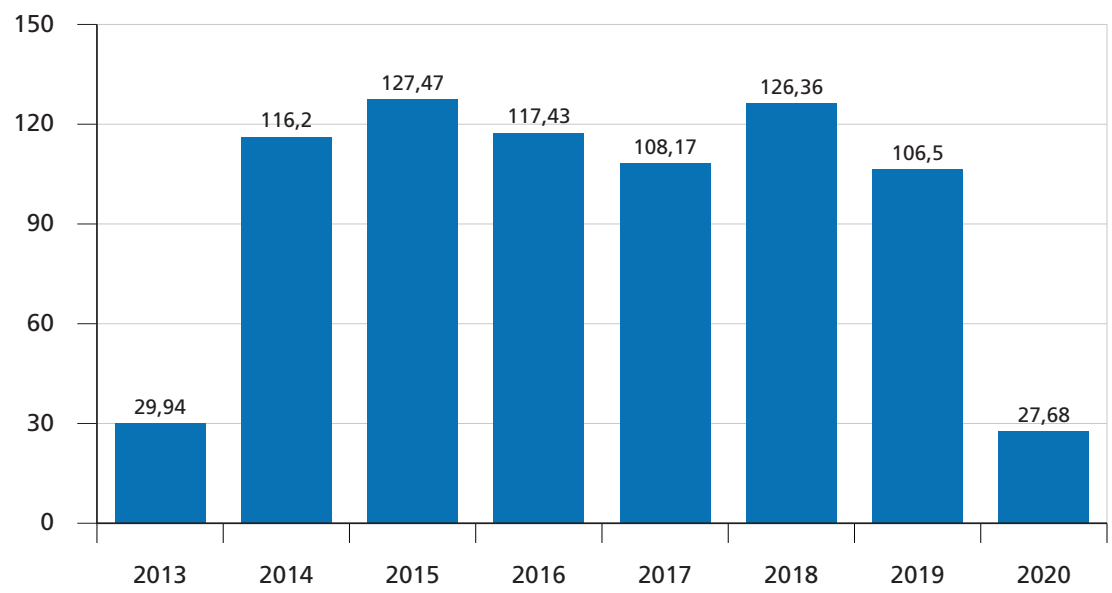

Fonte: American Enterprise Institute (AEI), 2020.

Elaboração dos autores.

17. No total, foram listadas 35 iniciativas envolvendo corredores econômicos e projetos de desenvolvimento e de infraestrutura dos países que compõem a Nova Rota da Seda.

18. No total, foram listadas catorze plataformas setoriais de cooperação multilateral que subsidiam a consecução da iniciativa, como a Belt and Road Energy Partnership e a Digital Silk Road Initiative. 
Em termos de distribuição setorial, os setores que mais se destacam são os de energia e de transportes. Combinados, ambos somam US\$ 482,34 bilhóes desde 2013 e representam mais de $63 \%$ dos investimentos chineses nos países da BRI. O gráfico 2 traz a distribuição setorial desses investimentos nos contratos de construção.

\section{GRÁFICO 2}

Distribuição setorial dos investimentos chineses e dos contratos de construção da BRI (2013-2020)

(Em \%)

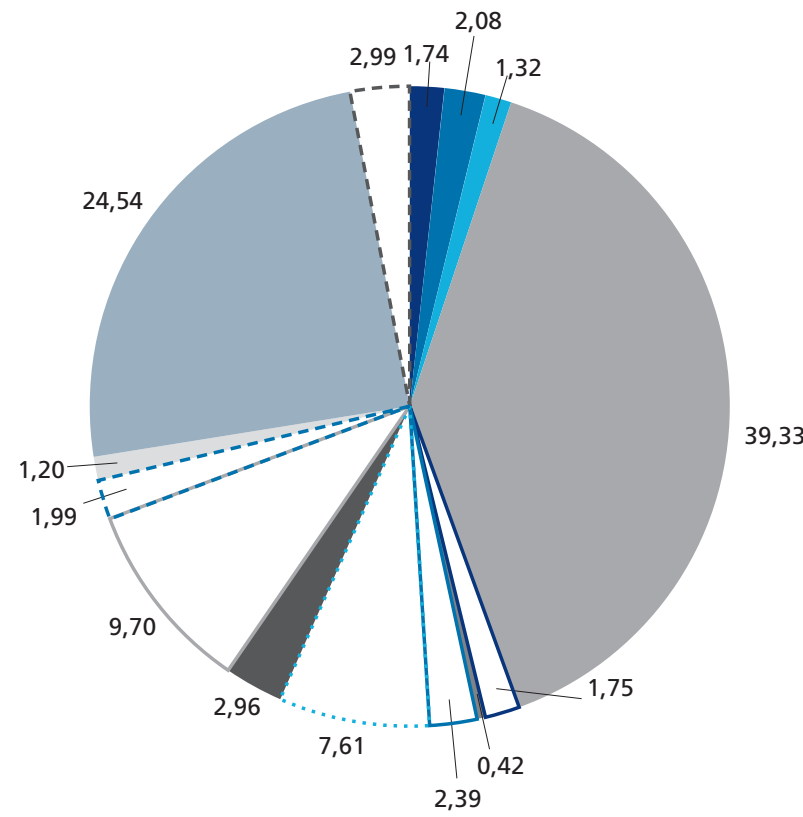

\begin{tabular}{|c|c|}
\hline Agricultura & Metais \\
\hline Químicos & Outros \\
\hline Entretenimento & $\square$ Imobiliário \\
\hline Energia & İ Tecnologia \\
\hline Financeiro & Turismo \\
\hline Saúde & Transportes \\
\hline Logística & I_ I Serviços pi \\
\hline
\end{tabular}

Fonte: AEl, 2020.

Elaboração dos autores.

$\mathrm{Na}$ Ásia, os setores de energia e transportes também se destacam quando identificados como projetos de infraestrutura da BRI. De acordo com a 
plataforma Reconnecting Asia, ${ }^{19}$ são 374 projetos de infraestrutura associados à iniciativa chinesa no continente. Estes projetos encontram-se separados nas seguintes categorias: i) intermodal (13); ii) gasodutos/oleodutos (7); iii) usinas geradoras de energia (146); iv) ferrovias (75); v) rodovias (102); vi) portos (25); e vii) linhas de transmissão de energia (6). Isto é, os setores de energia e transportes se destacam, alinhando-se ao propósito da iniciativa de promover a conectividade e a integração física, especialmente na Eurásia, mas não somente nela.

Em relação aos empréstimos e financiamentos, convém destacar a atuação proeminente de bancos públicos chineses, como o China Development Bank (CDB), que até 2019 já tinha comprometido US\$ 190 bilhóes em financiamento para projetos relacionados com a BRI (Staff, 2019). Considerando somente o setor energético e os países que integram a iniciativa, o CDB e o Export-Import Bank of China realizaram operaçôes de financiamento que superaram, entre 2013 e 2019, o montante de US\$ 114 bilhôes. ${ }^{20}$ Há, ainda, os Bancos Multilaterais de Desenvolvimento (BMDs) criados sob a liderança ou com a participação da China, que complementam os esforços de impulsionar os investimentos em infraestrutura na Ásia e fora dela. O AIIB, por exemplo, já possui mais de cem países-membros, noventa projetos aprovados e US\$ 19,80 bilhóes em financiamento para infraestrutura regional. ${ }^{21}$

Nesse sentido, sugerimos que a Nova Rota da Seda é um projeto chinês de globalização (Pautasso, Doria e Nogara, 2020), e que, visando contê-la, Washington tem reagido articulando um cerco geopolítico em torno do eixo sino-russo, o eixo estruturante do processo de integração eurasiático. É nessa direção que se deve compreender os desafios securitários, tais como os movimentos separatistas e terroristas que afetam a própria China, em Xinjiang, e a Rússia, na Chechênia, bem como a política estadunidense em prol do fomento aos litígios no Mar do Sul da China. A isso se soma a forte presença dos Estados Unidos na Bacia do Pacífico, que se estende passando por Coreia do Sul, Japão, Tailândia, Malásia e Filipinas, além de Guam e Havaí (Pautasso, 2019).

Outra questão complexa que atravessa a iniciativa chinesa refere-se às relaçóes sino-indianas. Ao estabelecer a dimensão marítima da Nova Rota da Seda, Pequim enseja a construção e modernizaçáo dos portos de: Colombo e Hambantota, no Sri Lanka; Gwadar, no Paquistão; Chittagong, no Bangladesh; Ilha Maday, em Mianmar; e Port Victoria, nas Seychelles. Esse arranjo de infraestrutura tem sido intitulado colar de pérolas, e é percebido pela Índia como um desafio à sua hegemonia regional (Pautasso, Nogara e Ribeiro, 2020).

19. Disponível em: <https://reconnectingasia.csis.org/map/>.

20. Disponivel em: <http://www.bu.edu/cgef/\#/2019/Country>.

21. 0 site oficial do AllB está disponível em: <https://www.aiib.org/en/index.html>. 
Por um lado, as interaçôes da Índia com os chineses expressam cooperação, em dimensões como o compartilhamento de participação na OCX, no AIIB - no qual os indianos detêm o segundo maior aporte - e, ainda que com desinteresse, no Corredor Econômico Bangladesh-China-Índia-Mianmar (Bangladesh, China, India and Myanmar Economic Corridor - BCIM) da Nova Rota da Seda. Por outro lado, a Índia desenvolve suas próprias iniciativas, além exibir notável desconforto com um dos eixos da Nova Rota da Seda: o Corredor Econômico China-Paquistáo, que fortalece a cooperação entre históricos rivais com os quais compartilha extensas fronteiras, em grande parte com limites ainda litigiosos e não plenamente demarcados. Com efeito, o sucesso da Nova Rota da Seda passa, inexoravelmente, pela consolidação das relaçôes chinesas com esse importante vizinho e contendor, com suas consequentes repercussóes diplomáticas.

Com a crise financeira de 2008 e a atual pandemia do coronavírus, o processo de transição sistêmica parece ter se acelerado. Diante da ascensão de forças disruptivas, a China tem demonstrado maior responsabilidade junto às instâncias multilaterais, e já no 18 o Congresso do PCCh, de 2012, reforçava o discurso voltado a contribuir para o desenvolvimento do continente (Jiemian, 2015, p. 5). Ou seja, trata-se de uma diplomacia de grande potência com características chinesas e com uma estratégia carregada de maior proatividade (Kejin e Xin, 2015, p. 48), combinando responsabilidade de grande poder com a defesa de interesses fundamentais como o desenvolvimento econômico e a integridade territorial (Zhao, 2011).

\section{A CHINA, A AMÉRICA LATINA E A NOVA ROTA DA SEDA}

As relaçóes entre China e América Latina foram impulsionadas, inicialmente, pelo acelerado desenvolvimento do país asiático e, com efeito, pelo gigantesco incremento da demanda por recursos naturais, energéticos e alimentares. Com o boom das commodities na primeira década do século XXI, rapidamente o mercado chinês se tornou o maior importador de quase todos os países da regiáo. Como resultado desse processo, o comércio entre China e América Latina saltou de US $\$ 12$ bilhōes, em 2000, para mais de US\$ 224 bilhóes, em 2016, representando uma multiplicação de dezesseis vezes ao longo desse período (González, 2018). Em 2019, as exportações latino-americanas somaram US\$ 141,5 bilhōes, enquanto as importaçóes oriundas da China foram da ordem de US\$ 161,7 bilhôes, totalizando mais de US\$ 300 bilhōes (Ray e Barbosa, 2020).

Para a América do Sul, a China já se consolidou como principal parceiro comercial, e quando considerada a América Latina como um todo, o país asiático se posicionou na segunda colocação, atrás dos Estados Unidos. A pauta exportadora da regiáo segue concentrada em produtos primários: os principais 
produtos de exportação permanecem sendo soja, petróleo cru e minérios (cobre e ferro). Em conjunto, esses produtos correspondem a mais da metade das exportaçóes da América Latina para a China. Alguns países apresentam superavit comerciais (Brasil, Peru e Chile) e outros, deficit (México e Colômbia) (Ray e Barbosa, 2020).

A presença da China no subcontinente tem se incrementado com a mobilização de crescentes somas em investimento, concessão de empréstimos e realizaçấo de projetos de infraestrutura. Como produto da modificação tanto na gestão das reservas cambiais da China no pós-crise de 2008 (Jaguaribe, 2018) quanto na ampliação da política going global, a América Latina também tem sido uma região receptora de investimentos chineses. Entre 2005 e 2020, a combinação do IED chinês e dos projetos de construção na América do Sul totalizou US\$ 178 bilhóes, sendo que, desse total, US\$ 165,78 bilhôes foram alocados na região após $2010 .{ }^{22} \mathrm{O}$ destaque vai para o setor energético, que concentrou grande parte desses investimentos e somou, entre 2005 e 2020, mais de US\$ 100 bilhôes.

O financiamento chinês para a América Latina também se incrementou de maneira significativa ao longo da última década, especialmente por meio da atuação de dois bancos públicos chineses: o CDB e o Export-Import Bank of China. Ambas as instituições financeiras realizaram empréstimos aos governos da América Latina e às empresas chinesas interessadas em ingressar no mercado da regiáo (Song, 2019). Desde 2005, essas instituiçóes emprestaram mais de US\$ 137 bilhōes a países da América Latina e Caribe (ALC) e empresas estatais, sendo os quatro primeiros, nessa ordem, Venezuela (US\$ 62,2 bilhóes), Brasil (US \$ 28,9 bilhôes), Equador (US \$ 18,4 bilhôes) e Argentina (US \$ 17,1 bilhóes). ${ }^{23}$ Os setores energético e de transportes igualmente se destacaram como principais receptores do financiamento chinês, concentrando grande parcela dos capitais alocados nos países latino-americanos.

Em termos de investimentos em infraestrutura, os países da ALC estão aderindo rapidamente àqueles disponibilizados pelo AIIB e pela BRI, ambos liderados pela China. As empresas e bancos chineses têm indicado interesse em aproximadamente 150 projetos de infraestrutura de transporte na ALC, e, até 2018, cerca de metade desses projetos havia entrado em alguma fase de construção. Entre as empresas que realizam esses projetos estáo gigantes da construção como a China Harbour Engineering Company (CHEC) e a China Railway Construction Corporation, além das petrolíferas chinesas Sinopec e Sinohydro. ${ }^{24}$ Com a

22. Conferir dados do China Global Investment Tracker, elaborado pelo AEl, disponíveis em: <https://www.aei.org/ china-global-investment-tracker/>.

23. Disponível em: <https://www.thedialogue.org/map_list/>.

24. Disponível em: <https://www.thedialogue.org/blogs/2018/11/chinas-transport-infrastructure-investment-in-lacfive-things-to-know/>. 
Operação Lava-Jato no Brasil - que desarticulou grande parte das empreiteiras nacionais -, a desidratação do Banco Nacional de Desenvolvimento Econômico e Social (BNDES) e o recuo da liderança do país na UNASUL, abriu-se um espaço para a China assumir protagonismo nesse âmbito.

De modo a elucidar essa crescente projeção econômica da China na América Latina, cabe exemplificar determinados projetos de investimento. No Brasil, o setor elétrico tem se caracterizado como principal receptor de capitais chineses, com atuação destacada das empresas State Grid e China Three Gorges. Além de vultosas aquisiçóes, como no caso da CPFL Energia, a State Grid liderou, em 2017, o consórcio responsável pela construção da primeira linha de transmissão de energia elétrica, de aproximadamente 2 mil quilômetros, que conecta a usina hidrelétrica de Belo Monte aos centros consumidores, no Sudeste do país. Em 2019, a segunda linha de transmissão, com extensão de 2,5 mil quilômetros, também foi concluída, tendo sido construída inteiramente pela State Grid, ao custo de US\$2,2 bilhôes (Ray e Barbosa, 2020).

O Peru tem sido outro destino preferencial de investimentos chineses, sobretudo no setor de cobre, a exemplo do projeto de Las Bambas, que recebeu US\$ 5,850 bilhôes em aportes financeiros e representa o maior empreendimento chinês no país sul-americano (Mesías, 2017). Já na Argentina, esses investimentos têm em parte se direcionado à construção de barragens para geração de energia hidrelétrica, ao passo que também se destaca o projeto de renovação da rede ferroviária Belgrano Cargas, em valor superior a US\$ 2 bilhôes (Stanley, 2019).

Paralelamente, a China tem procurado aumentar o acercamento institucional e multilateral com o subcontinente. Nesse sentido, deve-se destacar criação do Fórum China-CELAC e a assinatura de memorandos de entendimento e acordos de cooperação em torno da ampliação da BRI para a América Latina. Por exemplo, a China estabeleceu tratados de livre comércio com países da regiấo, ingressou como observador na Organização dos Estados Americanos (OEA) e se tornou membro do Banco Interamericano de Desenvolvimento (BID) e consultor do Mercado Comum do Sul (MERCOSUL) (Dehart, 2012). Além disso, o país asiático formou parcerias estratégicas com relevantes atores regionais, como Brasil, Argentina, Chile, México, Peru e Venezuela (Yu, 2015). No caso do Brasil, as relaçóes foram alçadas à condição de parceria estratégica global, em 2012. Ainda como evidência do caráter estratégico da América Latina para Pequim, cabe mencionar as publicaçóes, em 2008 e 2016, do China's Policy Paper on Latin America and the Caribbean ${ }^{25}$ cujo conteúdo detalha as áreas de cooperação e as convergências entre o gigante asiático e os países latino-americanos.

25. Disponiveis em: <https://bit.ly/3kFwAX3>; e <https://bit.ly/3s9YPzq>. 
Na ocasiāo do II Fórum China-CELAC, em 2018, sediado em Santiago, os governos latino-americanos e chinês emitiram uma declaraçâo especial sobre a Nova Rota da Seda (CELAC, 2018). Na nota, é expresso que a iniciativa é amplamente compartilhada pela comunidade internacional e se considera que os países da ALC constituem parte da extensão natural da Rota da Seda Marítima, bem como são participantes indispensáveis na cooperação internacional da BRI. Em termos bilaterais, dezenove países latino-americanos assinaram acordos de cooperação em torno da Nova Rota da Seda. Desses dezenove, oito países são da América do Sul (Bolívia, Chile, Equador, Guiana, Peru, Suriname, Uruguai e Venezuela), três, da América Central (Costa Rica, El Salvador e Panamá), e oito são do Caribe (Antígua e Barbuda, Barbados, Cuba, Dominica, República Dominicana, Granada, Jamaica e Trindade e Tobago). Destaca-se, ainda, que seis países sul-americanos que aderiram formalmente à BRI são também membros (prospectivos ou completos) do AIIB, sendo eles: Uruguai, Bolívia, Peru, Chile, Equador e Venezuela (Ray e Barbosa, 2020).

Considerando a consistente e progressiva evoluçáo do relacionamento sino-latino americano ao longo deste século, cabe elencar as açóes e perspectivas inseridas dentro desse contexto de ampliação do projeto chinês de globalização para o subcontinente. No primeiro BRF, em 2017, participaram os presidentes Mauricio Macri (Argentina) e Michelle Bachelet (Chile). Em comunicado emitido em conjunto com o presidente argentino, o presidente Xi Jinping já havia sinalizado o que mais tarde veio a ser referendado na declaração especial emitida pelo Fórum China-CELAC (CELAC, 2018), isto é, o subcontinente constitui uma "extensão natural" da BRI, ao mesmo tempo que representa uma plataforma de cooperação mutuamente benéfica.

Em dezembro de 2017, a Nova Rota da Seda chega concretamente à América Latina, com a assinatura de um memorando de entendimento entre a China e o Panamá. O país centro-americano, estratégico por questóes logísticas e de transportes, havia estabelecido relaçóes diplomáticas com Pequim apenas cinco meses antes. Neste curto espaço de tempo, houve o estabelecimento de dezenove acordos bilaterais, ${ }^{26}$ abrangendo temas como a construção de mecanismos de cooperação para financiamento de projetos, a viabilidade de se concretizar um tratado de livre comércio e a previsão de financiamentos para as áreas de energia hidrelétrica, infraestrutura de transportes e agricultura (Garzón, 2017).

Seguindo o Panamá, outras naçóes passaram a manifestar interesse e aderir à iniciativa chinesa. Na América do Sul, o Peru, que representa o segundo maior destino de IED chinês depois do Brasil (CEPAL, 2018), aderiu à iniciativa

26. Um resumo dos acordos assinados entre China e Panamá, elaborado pelo Ministério das Relações Exteriores panamenho, está disponível em: <https://www.mire.gob.pa/images/PDF/resumen_de_aceurdos.pdf>. 
em 2019, concretizando uma relação estratégica que se desenvolveu ao longo do século XXI, dada a magnitude da evolução do intercâmbio comercial e da presença de investimentos do país asiático a partir de 2007 (Mesías, 2017). A assinatura do memorando de entendimento sino-peruano ocorre dez anos após a assinatura do tratado de livre comércio entre os dois países e reforça as perspectivas de investimentos não somente no setor mineiro - como já acontece em projetos como os de Las Bambas, Toromocho (cobre) e Marcona (ferro) mas também em infraestrutura. Além da possibilidade de retomar o projeto da ferrovia bioceânica, a adesão peruana à iniciativa chinesa se assenta na expectativa de investimentos em projetos como o do megaporto de Chancay e de outro em Ilo (Liévano, 2019).

Por um lado, a entrada do Peru na BRI, sexta maior economia latino-americana, pode incentivar o ingresso de outros países do subcontinente, especialmente as maiores economias da regiấo, que ainda não aderiram à iniciativa chinesa (Brasil, Argentina, México e Colômbia). Por outro lado, o ingresso do Peru significa um outro movimento relevante, que diz respeito à boa acolhida da BRI na regiáo andina. Antes do Peru, outros países da região já haviam assinados acordos bilaterais com a China (Bolívia, Chile, Equador e Venezuela).

A Venezuela, principal receptora de financiamento chinês nas últimas décadas, firmou parceria para extensão do projeto da BRI no país em dezembro de 2017. O presidente Nicolás Maduro, em visita oficial a Pequim em 2018, agraciou os bilhóes de dólares recebidos para tornar realidade as empresas mistas no campo de petróleo, reiterando também a sólida relação sino-venezuelana (Castro e Fontdeglória, 2018). Entre os projetos que são bandeira da iniciativa chinesa, salienta-se a central termelétrica de La Cabrera e a usina elétrica de El Vigía (Liévano, 2019). O conturbado contexto político e social da Venezuela, porém, retrata um cenário de incertezas para o desenvolvimento de projetos vinculados à iniciativa chinesa.

Em junho de 2018, a Bolívia acordou participação na Nova Rota da Seda, buscando sobretudo investimentos em infraestrutura de transportes, como é o caso da ampliação de um trecho na rodovia que liga Santa Cruz de la Sierra a Cochabamba. Há, ainda, outros projetos envolvendo construção de estradas, bem como perspectivas para desenvolvimento da represa hidrelétrica de Rositas (Liévano, 2019). Outras atividades que podem ser impulsionadas pela BRI na Bolívia são a produção de quinoa ${ }^{27}$ e a exploração de lítio na região sul do país. Em 2019, o Grupo Xinjiang TBEA anunciou, em conjunto com a estatal boliviana Yacimientos de Litio Bolivianos (YLB), a criação de uma empresa mista

27. 0 então ministro das relações exteriores da Bolívia, Fernando Huanacuni, ressaltou a cooperação sino-boliviana e a qualidade da quinoa produzida no país, além da sua participação no comércio bilateral (China-Bolivia Cooperation..., 2018). 
para a construção de fábricas de carbonato de lítio nos salares de Coipasa, em Oruro, e Pastos Grandes, em Potosí (Jemio, 2020). O projeto, todavia, vem passando por escrutínio do governo provisório boliviano, lançando dúvidas sobre a possibilidade de sua execução (Ray e Barbosa, 2020).

O Chile ingressou na BRI em novembro de 2018, após visitas oficiais de uma comitiva liderada pelo presidente Sebastián Piñera a países asiáticos, entre eles a China. A expectativa é de reforço das trocas comerciais - a China já é o principal parceiro comercial do Chile -, tornando o país atrativo para maiores investimentos. Em 2019, em visita à Pequim, os presidentes de ambos os países novamente abordaram temas envolvendo comércio e investimento, prevendo também uma revisão do tratado de livre comércio entre eles. $\mathrm{O}$ entendimento é de que Santiago busca se posicionar enquanto um centro de negócios na América Latina, atraindo investimentos nos setores de tecnologia, inovação e comunicaçóes. ${ }^{28}$ Até o momento, o país sul-americano recebeu investimentos nos setores agrícola, mineiro e energético, totalizando US\$ 11,67 bilhóes entre 2005 e $2020 .^{29}$

Em dezembro de 2018, o Equador firmou a parceria com a China no sentido de aprofundar a cooperaçáo bilateral e ingressar na Nova Rota da Seda (Jingxi, 2018). O país, que é o terceiro destino de financiamento chinês na América Latina, espera que a iniciativa chinesa amplie os projetos de investimento, especialmente em infraestrutura de transportes e energia. De acordo com o presidente Lenín Moreno, a China é uma referência em termos de inovação e desenvolvimento, possuindo 145 empresas que trabalham e investem no Equador (Ecuador, 2018). O país sul-americano é o que mais tem projetos sob a bandeira da BRI, abrangendo obras de centrais hidrelétricas, empreendimentos em minas de cobre e modernização da infraestrutura de transportes (Liévano, 2019).

A Colômbia, por sua vez, constitui o único país andino às margens da Nova Rota da Seda na América Latina. Embora o governo colombiano reconheça a importância internacional da BRI, conforme sugerido pelo chanceler Carlos Holmes Trujillo, ${ }^{30}$ a política externa do novo presidente Iván Duque vem se centrando sobretudo na crise política venezuelana e na estratégia estadunidense para a região (Liévano, 2019). Em contrapartida, houve, em 2019, uma aproximação importante entre os dois países, como resultado da visita do presidente colombiano à China. Na visita, foram estabelecidos acordos em diversas áreas, envolvendo projetos de energia, construção de rodovias, comércio de frutas

28. Disponivel em: <https://www.reuters. com/article/chile-china-inversiones-idLTAKCN1S124Y>.

29. Disponivel em: <https://www.aei.org/china-global-investment-tracker/>.

30. Para Trujillo, "o desenvolvimento da infraestrutura é de fato um dos pilares da iniciativa e um dos aspectos mais interessantes, pois contribui para a conectividade entre as regiões" (El gobierno..., 2019, tradução nossa). 
e verduras, entre outros (Miranda, 2019). No geral, a Colômbia, principal aliada estadunidense na América Latina, vem adotando uma postura de cautela em relação à adesão na Nova Rota da Seda, apesar de interessada no aprofundamento dos laços de comércio e investimento, assim como em projetos em infraestrutura e no setor de energia.

Já o Uruguai assinou um memorando de entendimento com a China em agosto de 2018, sendo o primeiro país do MERCOSUL a aderir à iniciativa chinesa. A perspectiva é de que a Nova Rota da Seda possa contribuir à intensificação das relaçóes econômicas bilaterais. A China já é o principal parceiro comercial uruguaio e o principal importador de carne, celulose, soja e lã (Gang, 2018). Diferentemente de Montevidéu, os demais países do MERCOSUL não se juntaram à $\mathrm{BRI}$ formalmente. $\mathrm{O}$ Paraguai, por um lado, em virtude da manutenção de suas relaçóes diplomáticas com Taiwan, naturalmente encontra-se alijado de quaisquer intentos voltados à entrada na Nova Rota da Seda. Brasil e Argentina, por outro, encontram-se entre os principais receptores de investimento e financiamento chinês na América Latina, ao mesmo tempo que ambos possuem a China como seu principal parceiro comercial.

A Argentina, que inclusive participou do primeiro BRF em 2017, encontra-se em uma posição de reticência em relação à BRI. A despeito da associação estratégica integral e dos estreitos contatos, conforme demonstram declaraçóes bilaterais como a ocorrida em 2018 às margens da cúpula do Grupo dos Vinte (G20) em Buenos Aires, ${ }^{31}$ a segunda maior economia da América do Sul necessita renegociar sua dívida externa com credores privados e com o FMI, demandando um difícil equilíbrio nas relaçóes com os Estados Unidos e a China. A tendência, todavia, é de que Buenos Aires busque, por meio do ingresso na Nova Rota da Seda, estreitar os vínculos de comércio, investimento e financiamento, reativando projetos como os das represas de Santa Cruz e das centrais nucleares (Dalto, 2020).

Ainda assim, o cenário de acirramento da disputa sino-estadunidense e o contexto eleitoral dos Estados Unidos podem atrasar a adesão da Argentina à Nova Rota da Seda, apesar dos recentes movimentos da vice-presidente, Cristina Kirchner, voltados à negociação de um acordo bilateral com a China (Cantando, 2020). De todo modo, a China desponta inegavelmente como um parceiro estratégico, tendo em vista as urgentes necessidades de financiamento por parte do país sul-americano, a liderança chinesa e a sua capacidade de engenharia e financiamento em diversos setores de infraestrutura (ferrovias, energia nuclear, barragens hidrelétricas etc.) e a possibilidade de ampliação dos já existentes

31. Disponível em: <https://www.cancilleria.gob.ar/en/announcements/news/joint-statement-between-peoples-republicchina-and-argentine-republic>. 
empréstimos preferenciais e acordos de swap cambial, que servem para reforçar as reservas internacionais e estabilizar a taxa de câmbio (Stanley, 2019).

Ao contrário da Argentina, que vem pautando sua inserção internacional a partir de uma orientação que privilegia uma certa equidistância em relação aos confrontos entre China e Estados Unidos, o governo brasileiro vem adotando uma política externa de alinhamento automático aos interesses de Washington. Mesmo que Pequim cada vez mais se consolide como o principal parceiro econômico e comercial do Brasil, a diplomacia brasileira, desorientada e desarticulada, vem emitindo sinais ambíguos e respostas contraditórias no trato com a China. Isto posto, enxerga-se como improvável uma adesão formal do Brasil à BRI ao menos no curto e médio prazo, a despeito do país ser o principal receptor de IED chinês na América do Sul e o segundo maior captador de empréstimos e financiamentos chineses na América Latina (CEPAL, 2018; Recaj, 2020).

Deve-se mencionar, ainda, a projeção da BRI sobre o México e o conjunto da América Central e Caribe. Primeiramente, é oportuno ressaltar que os vínculos econômicos da China com os países da região são menos intensos do que com os da América do Sul, em razão da ausência de recursos naturais e minerais em abundância e da proximidade (geográfica, política, econômica e social) com os Estados Unidos (Herreros, 2018). Em segundo lugar, apesar do ingresso de diversos países caribenhos e centro-americanos na Nova Rota da Seda, interpreta-se que seus efeitos podem ser de alcance limitado, ainda mais se levarmos em consideração a ausência de endosso do México, que possui uma forte relação de interdependência com a economia estadunidense. A exceção, conforme abordado, pode ser o estreitamento das relaçóes sino-panamenhas, dada a posição geográfica estratégica do país para fins logísticos e de transporte.

\section{A ASCENSÃO CHINESA E OS DILEMAS DO REGIONALISMO LATINO-AMERICANO}

Desde a década de 1990, os países latino-americanos reduziram seus investimentos em infraestrutura a cerca de $1 \%$ do produto interno bruto (PIB), quando se considera que 4\% seja um nível aceitável (Gransow, 2015). A infraestrutura tem sido, historicamente, o óbice da integração subcontinental. Enquanto os Estados Unidos completaram ainda em meados do século XIX a ligação ferroviária Atlântico-Pacífico, a América do Sul, por exemplo, segue sem conexão ferroviária que conecte as duas costas. Dessa maneira, a eventual extensão da Nova Rota da Seda para a América Latina certamente pode vir a construir um novo cenário de oportunidades para a região.

Se inicialmente a BRI se orientava essencialmente, tanto na dimensão terrestre quanto na marítima, para as interligaçóes entre a China, a Eurásia 
e a costa oriental africana, mais contemporaneamente tem assumido forma global, o que inclui a América Latina. Até 2019, cerca de dezenove países latino-americanos já anunciaram disposição de se somar à BRI (Santoro, 2019). Com efeito, o subcontinente experimenta oportunidades e desafios decorrentes da rivalidade sino-estadunidense.

O recrudescimento dessa rivalidade vem se dando desde a eleição de Trump, em 2016, quando os Estados Unidos desencadearam a guerra comercial. Sob a bandeira do America First, Washington utiliza-se da retórica antichinesa tanto para unificar sua base eleitoral conservadora quanto para legitimar o protecionismo e dirimir os enormes deficit no comércio com o gigante asiático. As disputas tarifárias, por sua vez, refletem a perda de competitividade técnico-produtiva estadunidense e, por isso, o cerne do litígio é o domínio tecnológico sobre a infraestrutura de comunicação 5G, sob liderança global da empresa chinesa Huawei. Afinal, é sabido que a dianteira tecnológica e geoeconômica impacta conversóes de poderes geopolíticos.

É por isso que o recente discurso de Mike Pompeo em A China Comunista e o Futuro do Mundo Livre ${ }^{32}$ retomou a narrativa da nova Guerra Fria. Ele instou "uma luta entre o mundo livre e a tirania", e acusou o PCCh de ser um "opressor nacional" e um "agente internacional desonesto". Ou seja, novamente, Washington tem recuperado elementos retóricos para conter a China, percebida como um país desafiante e comandado por um partido comunista, ao passo que busca unificar seus aliados como no período da bipolaridade. Todavia, a história não se replica: desde os anos 1970, a diplomacia chinesa se pauta pelo pragmatismo, pelo respeito ao princípio da não intervenção em assuntos domésticos e, mais contemporaneamente, pela busca da promoção das chamadas relaçôes win-win. Assim, diferentemente da União das Repúblicas Socialistas Soviéticas (URSS), enquanto Pequim busca a dianteira técnico-produtiva e o fortalecimento dos organismos multilaterais, Washington, em oposição, reforça sua política de contenção por meio de desestabilizaçóes e intervenções.

Em âmbito hemisférico, tal dinâmica se replica. Durante a Guerra Fria, os Estados Unidos enfatizaram a dimensão ideológica e securitária - com a criação da OEA e do Tratado Interamericano de Assistência Recíproca (TIAR) no pós-Segunda Guerra Mundial -,${ }^{33}$ enquanto grande parte dos países latino-americanos reivindicava centralidade à cooperação econômico-comercial, demandando investimentos em infraestrutura, crédito acessível e mecanismos de ajuda ao desenvolvimento. Caso emblemático dessa contradição, a proposição

32. A íntegra do discurso está disponível em: <https://br.usembassy.gov/pt/a-china-comunista-e-o-futuro-do-mundo-livre/>. 33. Segundo Cervo (2008), a construção de tal sistema interamericano dialogava com a imposição de dois objetivos estratégicos dos Estados Unidos no concerto hemisférico: a garantia do livre fluxo de capitais estadunidenses e a ênfase na dimensão securitária da cooperação multilateral, no contexto de combate ao comunismo. 
brasileira da Operação Pan-Americana (OPA), durante o governo de Juscelino Kubitscheck, conectava discursivamente a necessidade de subsídios para o desenvolvimento com o objetivo central estadunidense de combater o comunismo no conjunto do sistema internacional. Ainda que tal iniciativa tenha influenciado a criação do BID e mesmo da Aliança para o Progresso - já no contexto de repercussão regional da Revolução Cubana -, ela não foi plenamente atendida, e os recursos disponibilizados estiveram longe de emular o Plano Marshall pretendido pelos países ao sul de Rio Bravo.

Nesse quadro, a capacidade de barganha da América Latina era reduzida, pois as principais políticas estadunidenses de assistência ao desenvolvimento ocorreram nas chamadas fronteiras quentes da Guerra Fria e a URSS não vislumbrava a regiáo no escopo de sua projeção estratégica (Visentini, 2013). Diante das limitaçóes impostas pelo cenário da ordem bipolar, os países latino-americanos apostaram na conformação de distintos e fragmentados mecanismos multilaterais de cooperação. Com maior alcance e amplitude, constaram iniciativas como a Associação Latino-Americana de Livre Comércio (ALALC), o Sistema Econômico Latino-Americano e do Caribe (SELA), a Associação Latino-Americana de Integração (ALADI) e o Mecanismo Permanente de Consulta e Concertação Política da América Latina e do Caribe (Grupo do Rio), desdobramento das articulaçóes entre o Grupo de Contadora e o Grupo de Apoio à Contadora. Territorialmente localizados, surgiram instrumentos de cooperação tais como o Pacto Andino, o Tratado de Cooperaçáo Amazônica (TCA), a Organização dos Estados Centro-Americanos (ODECA), o Mercado Comum Centro-Americano (MCCA) e o Mercado Comum e Comunidade do Caribe (Caricom). A geometria variável desses distintos e complexos arranjos levou Tokatlian (2012) a cunhar o conceito de complexo integracionista, englobando o conjunto de interaçóes entre elementos de integração, concertação, união, cooperação, regionalismo e multilateralismo.

Com o fim da Guerra Fria, os Estados Unidos lançaram a Iniciativa para as Américas, em junho de 1990, retomando proposiçóes para o pan-americanismo, somando-se à imposiçáo da agenda liberalizante mediante o Consenso de Washington, de 1989. A dimensão comercial da iniciativa teria sua materialização apresentada apenas em 1994 com as negociaçôes para a implantação de uma futura Área de Livre Comércio das Américas (ALCA).

Paralelamente, os mecanismos de cooperaçáo propriamente latino-americanos passaram por profunda rearticulaçáo, em grande parte aderindo ao paradigma do regionalismo aberto. Nesse sentido, a aproximação de Brasil e Argentina, antes 
gradualista e calcada em ideais desenvolvimentistas, ${ }^{34}$ resultou na conformação do MERCOSUL, junto de Uruguai e Paraguai, em 1991; o Pacto Andino foi rebatizado, dando origem à Comunidade Andina de Naçóes (CAN), em 1996; os países centro-americanos, com exceção do México, proporcionaram a criação do Sistema de Integração Centro-Americano (SICA), em 1991; e os mexicanos estabeleceram, junto dos Estados Unidos e do Canadá, o Tratado Norte-Americano de Livre Comércio (NAFTA), em 1994, como desdobramento do anterior Acordo de Liberalizaçáo Econômica, firmado em 1988 por Washington e Ottawa.

Ainda assim, a reticência de diversos países diante das eventuais consequências da adesão à ALCA para suas indústrias nacionais resultou em um prolongamento das discussóes acerca de sua implementação. Da mesma forma, as condicionalidades para adesão aos mecanismos de renegociação da dívida e de disponibilização de auxílio econômico impostas pelo FMI e o Banco Mundial geraram impasses. Exemplos evidentes das tentativas de contrabalançar tal situação foram as movimentaçóes brasileiras em prol da potencialização do alcance comercial do MERCOSUL, da proposiçáo de Área de Livre Comércio Sul-Americana (ALCSA) e mesmo da organização da Cúpula de Brasília, que reuniu pela primeira vez o conjunto dos presidentes sul-americanos, resultando na conformação da Iniciativa para a Integração da Infraestrutura Regional Sul-Americana (IIRSA). ${ }^{35}$

Essa conjuntura de desconfiança no que se refere aos desígnios hemisféricos estadunidenses, novamente insuficientes em termos de assistência ao desenvolvimento, aliou-se ao processo de ascensão de governos dirigidos por forças políticas de esquerda e centro-esquerda na América Latina, e principalmente na América do Sul. Consequentemente, em 2005 os avanços da proposição da ALCA foram finalmente estancados, tendo em vista as recusas tanto de grande parte dos países latino-americanos quanto dos próprios Estados Unidos ${ }^{36} \mathrm{em}$ ceder nas negociaçôes de liberalização comercial e abertura de seus mercados nacionais.

Nesse ínterim, avançaram novamente proposições de mecanismos regionais multilaterais às margens da OEA e sem a participação dos Estados Unidos, orientadas por paradigmas distintos do regionalismo aberto até então

34. Conforme Bandeira (2010b), o modelo de integração anteriormente acertado por Sarney e Alfonsín privilegiava o setor de bens de capital e a cooperação científica e tecnológica, além do estabelecimento de normas visando resguardar o equilíbrio e a simetria no desenvolvimento das relações econômicas e comerciais bilaterais, evitando a especialização setorial dos sistemas produtivos e eventuais saldos negativos no intercâmbio.

35. Cabe mencionar que, um dia antes da realização da Cúpula de Brasília, Bill Clinton, então presidente dos Estados Unidos, anunciou a implantação do Plano Colômbia, ensejando cooperação com os colombianos para o combate ao narcotráfico e às guerrilhas no país (Bandeira, 2010b).

36. Visentini (2013) destacou que, ao longo da gestão de George Bush, os estadunidenses vinham enfatizando contrariedade à possibilidade de cessar os enormes subsídios que concediam para a agricultura nacional, bem como às pressões pela mitigação do protecionismo vinculado a produtos como o aço. 
preponderante. Exemplos da materialização dessa nova etapa do regionalismo, ${ }^{37}$ que Sanahuja (2014) intitulou de regionalismo pós-liberal, foram as ascensões da Comunidade Sul-Americana de Naçóes (CASA), da UNASUL, da Aliança Bolivariana para os Povos da Nossa América-Tratado de Comércio dos Povos (ALBA-TCP) e da CELAC.

Foi nesse contexto que a China, com seu vigoroso processo de desenvolvimento econômico e já inserida na OMC, passou a, progressivamente, aparecer como ainda mais relevante parceria bilateral e mesmo multilateral dos países latino-americanos, tal como exemplificou a articulação do Fórum China-CELAC, em 2014. As elucubrações acerca da implementação da BRI na América Latina se inserem, portanto, nesse panorama mais amplo, no qual a China não aparece apenas como uma vigorosa parceira individual dos países da região, mas como uma alternativa viável às demandas de subsídios ao desenvolvimento escassamente atendidas desde a plena conformação das ferramentas multilaterais hemisféricas, ao final da Segunda Guerra Mundial.

Apesar do vigoroso e remanescente poderio de Washington, são evidentes suas dificuldades em fornecer mecanismos de cooperação capazes de rivalizar com os chineses em determinados segmentos das esferas comercial e financeira, tais como os investimentos em infraestrutura. Mesmo aqueles países dispostos a aderir à antiga proposição do Acordo de Associação Transpacífico (TPP), aglutinados sob a sigla da Aliança do Pacífico, se viram frustrados diante do recuo estabelecido pelo governo Trump na sua implementação. Consequentemente, é na velha alternativa do recrudescimento das dimensôes securitária e político-ideológica da cooperação, aos moldes da antiga Guerra Fria, que os Estados Unidos investem atualmente como baluarte de sua estratégia de contenção da China, seja no mundo Eurasiático, na África ou mesmo na América Latina. Tal estratégia, no entanto, tem encontrado dificuldades, exatamente pela distinção do padrão de interação estabelecido no passado pela URSS e hoje pela China com os países da regiâo.

Paradoxalmente, a sequencial queda dos governantes de esquerda e centro-esquerda da América Latina pode inclusive favorecer a China. Afinal, o refluxo de iniciativas tais como a da UNASUL e da CELAC, a desidratação da liderança regional do Brasil (Vaz e Nogara, 2020), o retraimento da participaçáo dos bancos de fomento - Corporação Andina de Fomento (CAF) e BNDES - em obras de infraestrutura e o processo de desarticulação das empreiteiras brasileiras limitaram as alternativas propriamente regionais aos dilemas econômicos locais. Portanto, quando os Estados Unidos não fornecem mecanismos substitutivos para

37. Apesar de várias iniciativas do período se inserirem, com maior ou menor grau, nessa nova etapa, diversas foram as diferenças de orientação de suas movimentações. Tais desacordos, rivalidades e impasses foram retratados em uma série de pesquisas, entre as quais estão as de Almeida (2014), Bernal-Meza (2013; 2015), Ruiz (2013), Katz (2006; 2016), Malamud (2009), Sanahuja (2010; 2012; 2014) e Serbin (2010). 
tais demandas, abrem espaço para o fortalecimento das iniciativas de Pequim, notadamente da Nova Rota da Seda.

Consequentemente, mesmo diante do giro à direita dos governos da região o efeito gravitacional da China segue sendo notável, demonstrando que a centralidade de tais vínculos não remete às questóes ideológicas. Os casos de Brasil e Chile são emblemáticos: o mercado chinês absorveu US\$ 35,77 bilhóes em exportaçóes brasileiras entre janeiro e julho de 2019 e, em 2020, no mesmo período, esse valor subiu para US\$ 41,16 bilhóes, enquanto os Estados Unidos caíram de US\$17,46 bilhóes para US\$ 11,73 bilhóes. ${ }^{38}$ No caso do Chile, a mesma situação: entre janeiro e julho de 2020, a China importou 35,8\% dos produtos chilenos, e os Estados Unidos, 14,3\%. Nos dois primeiros semestres de 2019, as exportaçóes chilenas para a China representaram 32,41\% do total, enquanto as exportaçóes para os Estados Unidos constituíam 15,09\% (Banco Central de Chile, 2020). Embora em uma intensidade menor do que a verificada no Brasil, os dados do comércio exterior chileno igualmente mostram uma redução das exportaçóes aos Estados Unidos e um aumento das exportaçóes para a China, mesmo no contexto da pandemia do coronavírus.

Aliás, o surto pandêmico também abre margens para novas oportunidades de cooperação, especialmente nos setores de saúde e de tecnologia digital (Koop, 2020). A Rota da Seda da Saúde e a Rota da Seda Digital podem criar novas dimensóes de cooperação e consolidar, por exemplo, a instalação de redes de 5G na regiáo - a despeito deste tema envolver também o acirramento da competição estratégica sino-estadunidense pela dianteira da inovação tecnológica e produtiva. Recentes projeçóes de CEPAL (2020) indicaram que a contração das exportações latino-americanas para os Estados Unidos deve atingir cerca de 32\% em 2020, enquanto os envios para a China tendem a ser reduzidos em apenas $4 \%$.

Isso posto, o fato é que, praticamente indiferente às mudanças político-ideológicas dos governos, a interação da China com os países da regiấo aumenta. Além disso, o modelo de cooperaçáo ensejado pela Nova Rota da Seda dispensa o multilateralismo como caminho central para sua implementação, podendo se beneficiar, ainda que indiretamente, da desarticulação do antes virtuoso ciclo do regionalismo latino-americano.

\section{CONSIDERAÇÕES FINAIS}

A China se converteu em uma relevante potência econômica, com capacidade de exercer grande poder gravitacional não apenas no seu entorno territorial imediato mas também em outras importantes regióes do mundo. Assim, mesmo 
não sendo a América Latina uma regiáo de interesse prioritário para a diplomacia chinesa, o país asiático tem se tornado o maior parceiro comercial e investidor de quase todos os países do subcontinente. Se, por um lado, os Estados Unidos não têm conseguido proporcionar alternativas de desenvolvimento para a região, a China, por outro, tem sido não só uma grande importadora de commodities como também uma grande investidora em infraestrutura. Consequentemente, Washington tem fortalecido, dentro de sua estratégia de contenção da ascensão chinesa, a retórica em prol do desencadeamento de uma nova Guerra Fria.

Diante do enfraquecimento dos mecanismos multilaterais de cooperaçáo e concertação política regionais, tais como a CELAC e a UNASUL, e das dificuldades dos Estados Unidos de suprir as demandas comerciais e financeiras latino-americanas, as possibilidades de avanço da presença chinesa aumentam. É nesse sentido que a Nova Rota da Seda ganha ainda mais relevância, tanto por enfatizar um aspecto central das históricas vulnerabilidades regionais, a infraestrutura, quanto por poder ser implementada dispensando os percalços da formatação de amplos organismos multilaterais. Se estabelecendo na América Latina, definitivamente a iniciativa chinesa se globaliza com ênfase na infraestrutura e produção, gerando uma alternativa ao paradigma da globalização neoliberal irradiado de Washington.

Apesar de o giro político-ideológico de parte dos governos latino-americanos ter ensejado a potencializaçáo da retórica em favor do alinhamento com Washington, é na força gravitacional da economia chinesa que, gradualmente, tem se encontrado o eixo norteador da inserção internacional da região. Em suma, navegar nas águas da transição sistêmica é uma tarefa complicada, e que pode ser ainda mais árdua e complexa no caso de a regiáo internalizar, acriticamente, as clivagens de uma suposta nova Guerra Fria ao invés de explorar pragmaticamente as vantagens da competição sino-estadunidense.

\section{REFERÊNCIAS}

ALMEIDA, P. R. A grande fragmentação na América Latina: globalizados, reticentes e bolivarianos. Carta Internacional, v. 9, n. 1, p. 79-93, 2014.

AMÉRICA LATINA terá pior período de crescimento em 70 anos, diz Cepal. Exame, 12 dez. 2019. Disponível em: <https:/exame.com/economia/americalatina-tera-pior-periodo-de-crescimento-em-70-anos-diz-cepal/>.

ARRIGHI, G. Adam Smith em Pequim: origens e fundamentos do século XXI. São Paulo: Boitempo, 2008.

BANCO CENTRAL DE CHILE. Indicadores de comercio exterior: segundo trimestre 2020. Santiago: Banco Central de Chile, 2020. 
BANDEIRA, L. A. M. Brasil, Argentina e Estados Unidos: conflito e integração na América do Sul - da Tríplice Aliança ao MERCOSUL (1870-2003). Rio de Janeiro: Civilização Brasileira, 2010a.

. Geopolítica e política exterior: Estados Unidos, Brasil e América do Sul. Brasília: FUNAG, 2010b.

BERNAL-MEZA, R. Modelos o esquemas de integración y cooperación en curso en América Latina (UNASUR, Alianza del Pacífico, ALBA, CELAC): una mirada panorámica. Berlin: Ibero-Amerikanisches Institut, 2013.

. Alianza del Pacífico versus ALBA y MERCOSUR: entre el desafío de la convergencia y el riesgo de la fragmentación de Sudamérica. Pesquisa e Debate, v. 26, n. 1(47), p. 1-34, 2015.

CANTANDO, M. Cristina negocia la adhesión de Argentina a la ruta de la seda de China. La Política Online, 22 agosto 2020. Disponível em: <https://www. lapoliticaonline.com/nota/128775-cristina-negocia-la-adhesion-de-argentina-ala-ruta-de-la-seda-de-china/>.

CARBAJOSA,A.Não hápandemia que freieotrem chinês no coração daEuropa. El País, 16 ago. 2020. Disponível em: <https://brasil.elpais.com/internacional/2020-08-16/ nao-ha-pandemia-que-freie-o-trem-chines-em-duisburgo.html> .

CASTRO, M.; FONTDEGLÓRIA, X. Nicolás Maduro visita China en busca de ayuda para Venezuela. El País, 15 sept. 2018. Disponível em: <https://elpais. com/internacional/2018/09/14/actualidad/1536888931_166748.html>.

CELAC - COMUNIDADE DE ESTADOS LATINO-AMERICANOS E CARIBENHOS. Special declaration of Santiago of the II Ministerial Meeting of the CELAC-China Forum on the Belt and Road Initiative. Santiago: CELAC, Jan. 2018. Disponível em: <http://www.itamaraty.gov.br/images/2ForoCelacChina/ Special-Declaration-II-CELAC-CHINA-FORUM-FV-22.1.18.pdf>.

CEPAL - COMISSÃO ECONÔMICA PARA A AMÉRICA LATINA E O CARIBE. Explorando nuevos espacios de cooperación entre América Latina y el Caribe y China. Santiago: CEPAL, 2018.

Los efectos del Covid-19 en el comercio internacional y la logística. Santiago: CEPAL, 2020. (Informe Especial Covid-19, n. 6).

CERVO, A. L. Inserção internacional: formação dos conceitos brasileiros. São Paulo: Saraiva, 2008.

CHINA-BOLIVIA COOPERATION: various agreements signed including MOU on Belt and Road Initiative. CGTN, 6 Sept. 2018. Disponível em: <https://news. cgtn.com/news/7a55544f35454464776c6d636a4e6e62684a4856/share_p.html>. 
DALTO, V. Crise afeta adesão da Argentina à Iniciativa do Cinturão e da Rota. Diálogo Chino, 12 ago. 2020. Disponível em: <https://dialogochino.net/pt$\mathrm{br} /$ comercio-e-investimento-pt-br/36865-crise-afeta-adesao-da-argentina-ainiciativa-do-cinturao-e-da-rota/ $>$.

DEHART, M. Remodelling the global development landscape: the China model and South-South cooperation in Latin America. Third World Quarterly, v. 33, n. 7, p. 1359-1375, 2012.

ECUADOR. Presidencia de la República. Foro de negocios en China. Beijing: Presidencia de la República, dic. 2018. Disponível em: <https://www. presidencia.gob.ec/wp-content/uploads/downloads/2018/12/2018.12.11FORO-NEGOCIOS-BEIJING.pdf>.

EL GOBIERNO evalúa si entrar en la Ruta de la Seda de China. Portafolio, 1 mayo 2019. Disponível em: <https://www.portafolio.co/economia/el-gobiernoevalua-si-entrar-en-la-ruta-de-la-seda-de-china-529117>.

GANG, W. Uruguay y la Franja y la Ruta: un acuerdo que promete horizontes positivos. El Observador, 23 agosto 2018. Disponível em: <https://www. elobservador.com.uy/nota/uruguay-y-la-franja-y-la-ruta-2018823500>.

GARZÓN, P. La Ruta de la Seda aterriza en el Canal de Panamá. Diálogo Chino, 5 dic. 2017. Disponível em: <https://dialogochino.net/es/infraestructuraes/10233-la-ruta-de-la-seda-aterriza-en-el-canal-de-panama/>.

GOLDMAN alerta para recessão na América Latina pior que da década de 80 . InfoMoney, 27 mar. 2020. Disponível em: <https://www.infomoney.com.br/ economia/goldman-alerta-para-recessao-na-america-latina-pior-que-da-decadade- $80 />$.

GONZÁLEZ, A. Latin America-China trade and investment amid global tensions: a need to upgrade and diversify. Washington: Atlantic Council, 2018. Disponível em: <https://www.atlanticcouncil.org/wp-content/uploads/2018/12/ Latin-America-China-Trade-and-Investment-Amid-Global-Tensions.pdf>.

GRANSOW, B. Chinese investment in Latin American infrastructure: strategies, actors, and risks. In: PETERS, E. D.; ARMONY, A. C. Beyond raw materials: who are the actors in the Latin America and Caribbean-China relationship? Distrito Federal: RED ALC-China, 2015.

HERREROS, S. La Franja y la Ruta: algunas reflexiones desde américa latina. In: GARCÍA, A. O. (Org.). China: BRI o el nuevo camino de la seda. Distrito Federal: Instituto de Investigaciones Jurídicas/Universidad Nacional Autónoma de México, 2018. 
JAGUARIBE, A. (Org.). Direction of Chinese global investments: implications for Brazil. Brasília: FUNAG, 2018.

JEMIO, M. T. Em momento de transição política, Bolívia repensa como industrializar seu lítio. Diálogo Chino, 19 maio 2020. Disponível em: <https:// dialogochino.net/pt-br/industrias-extrativistas-pt-br/35423-em-momento-detransicao-politica-bolivia-repensa-como-industrializar-seu-litio/>.

JIEMIAN, Y. China’s new diplomacy under the Xi Jinping administration. China Quarterly of International Strategic Studies, v. 1, n. 1, p. 1-17, 2015.

JINGXI, M. Xi welcomes Ecuador to help build Belt, Road. China Daily, 13 Dec. 2018. Disponível em: <https://www.chinadaily.com.cn/a/201812/13/ WS5c116128a310eff303290ad7.html>.

KATZ, C. El rediseńo de América Latina: ALCA, Mercosur y ALBA. Buenos Aires: Ediciones Luxemburg, 2006.

. Neoliberalismo, neodesarrollismo, socialismo. Buenos Aires: Batalla de Ideas, 2016.

KEJIN, Z.; XIN, G. Pursuing the Chinese dream: institutional changes of Chinese diplomacy under president Xi Jinping. Quarterly of International Strategic Studies, v. 1, n. 1, p. 35-57, 2015.

KISSINGER, H. Sobre a China. Rio de Janeiro: Objetiva, 2011.

KOOP, F. Coronavirus reshapes Belt and Road in Latin America. Diálogo Chino, 30 July 2020. Disponível em: <https://dialogochino.net/en/infrastructure/36699coronavirus-reshapes-belt-and-road-in-latin-america/>.

LIÉVANO, A. B. ¿Cómo avanza la Franja y la Ruta en la región andina? Diálogo Chino, 18 jun. 2019. Disponível em: <https://dialogochino.net/es/ infraestructura-es/27815-como-avanza-la-franja-y-la-ruta-en-la-region-andina/>. MALAMUD, A. Fragmentação e divergência na América Latina. Relaçóes Internacionais, n. 24, p. 61-73, dez. 2009.

MESÍAS, A. Impacto de China en la economía peruana. In: PETERS, E. D. (Ed.). América Latina y el Caribe y China: economía, comercio e inversión 2017. Ciudad de México: RED ALC-China, 2017.

MIRANDA, B. La audaz alianza de China con Colombia, el "mejor amigo" de Estados Unidos en Latinoamérica. BBC News, 26 agosto 2019. Disponível em: $<$ https://www.bbc.com/mundo/noticias-america-latina-49377586>.

NDRC - NATIONAL DEVELOPMENT AND REFORM COMMISSION. Vision and actions on jointly building Silk Road Economic Belt and 21st-century Maritime Silk Road. [s.l.]: NDRC, 2015. 
NOGARA, T. S. Crítica ao conceito de subimperialismo: a dimensão sul-americana da política externa brasileira e as limitaçóes das análises dependentistas. Monçóes, v. 9, 2020.

PAUTASSO, D. A Nova Rota da Seda e seus desafios securitários: os Estados Unidos e a contenção do eixo sino-russo. Estudos Internacionais, v. 7, 2019.

PAUTASSO, D.; DORIA, G.; NOGARA, T. S. A Nova Rota da Seda e o projeto chinês de globalização. Insight Inteligência, v. 90, 2020.

PAUTASSO, D. et al. A China e o mundo: a presença da China na África e o mito do "neocolonialismo chinês". Portal Bonifácio, 4 jul. 2020. Disponível em: <https://bonifacio.net.br/a-presenca-da-china-na-africa-e-o-mito-do-neocolonialismo-chines/>.

PAUTASSO, D.; NOGARA T. S.; RIBEIRO, E. H. A Nova Rota da Seda e as relaçóes sino-indianas: o desafio do "colar de pérolas". Mural Internacional, v. $11,2020$.

RAY, R.; BARBOSA, P. H. B. China-Latin American economic bulletin, 2020 edition. Boston: Global Development Policy Center, 2020. Disponível em: $<$ https://www.bu.edu/gdp/2020/03/18/new-china-latin-american-economicbulletin-2020/>.

RECAJ, C. M. El financiamiento chino en América Latina y el Caribe en el contexto de las relaciones económicas bilaterales. In: PETERS, E. D. (Org.). América Latina y el Caribe-China: economía, comercio e inversión 2019. Ciudad de México: RED ALC-China, 2020.

RODRIGUES, B.; HENDLER, B. Investimento externo chinês na América Latina e no Sudeste Asiático: uma análise de escopo, valores e setores-alvo. Estudos Internacionais, Belo Horizonte, v. 6, n. 3, p. 5-25, 2018.

RUIZ, J. B. Ejes y modelos en la etapa actual de la integración económica regional en América Latina. Estudios Internacionales, v. 175, p. 9-39, 2013.

SANAHUJA, J. A. La construcción de una región: Suramérica y el regionalismo postliberal. In: CIENFUEGOS, M.; SANAHUJA, J. A. (Ed.). Una región en construcción: UNASUR y la integración en América del Sur. Madrid: Fundación CIDOB, 2010. p. 87-136.

- Regionalismo post-liberal y multilateralismo en Sudamérica: el caso de UNASUR. In: SERBIN, A.; MARTÍNEZ, L.; RAMAZINI JÚNIOR, H. El regionalismo 'post-liberal' en América Latina y el Caribe: nuevos actores, nuevos temas, nuevos desafíos. Buenos Aires: CRIES, 2012. 
. Seguridad y defensa en Suramérica: regionalismo, cooperación y autonomía en el marco de UNASUR. In: SERBIN, A.; MARTÍNEZ, L.; RAMAZINI JÚNIOR, H. (Coord.). Atlántico vs. Pacífico? América Latina y el Caribe, los cambios regionales y los desafíos globales. Buenos Aires: CRIES, 2014.

SANTORO, M. Cinturōes e rotas: o programa de investimentos globais da China e as oportunidades para o Brasil. Carta Brasil-China, v. 23, 2019.

SERBIN, A. Regionalismo y soberanía nacional: los nuevos desafíos. Buenos Aires: CRIES-Nueva Sociedad, 2010.

SHAMBAUGH, D. China goes global: the partial power. New York: Oxford University Press, 2013.

SONG, X. Financing of China's policy banks in Latin America and the Caribbean. In: PETERS, E. D. (Ed.). China's financing in Latin America and the Caribbean. Distrito Federal: Universidad Nacional Autónoma de México, 2019. p. 65-83.

STAFF, R. China Development Bank provides over $\$ 190$ billion for Belt and Road projects. Reuters, 27 Mar. 2019. Disponível em: <https://www.reuters. com/article/us-china-finance-cdb-bri/china-development-bank-provides-over190-billion-for-belt-and-road-projects-idUSKCN1R8095>.

STANLEY, L. E. Argentina's infrastructure gap and financial needs: the role of china. In: PETERS, E. D.; ARMONY, A. C.; CUI, S. (Ed.). Building development for a new era: China's infrastructure projects in Latin America and the Caribbean. Ciudad de México: RED ALC-China, 2018.

China's OFDI in Argentina. In: PETERS, E. D. (Ed.). China's foreign

direct investment in Latin America and the Caribbean: conditions and challenges. Distrito Federal: Universidad Nacional Autónoma de México, 2019.

STUENKEL, O. O mundo pós-ocidental. Rio de Janeiro: Zahar, 2018.

TOKATLIAN, J. G. Latinoamérica y el complejo integracionista: un concepto a debate. Desarrollo Económico, v. 51, n. 204, p. 475-492, 2012.

VAZ, A. C.; NOGARA, T. S. Evolución y ejes de la política exterior brasileña contemporánea. Anuario Internacional CIDOB, v. 30, p. 248-256, 2020.

VISENTINI, P. F. A projeção internacional do Brasil: 1930-2012. Rio de Janeiro: Elsevier, 2013.

XI e premiê grego visitam Porto de Piraeus e elogiam a cooperação sob Iniciativa do Cinturão e Rota. Xinhua, 12 nov. 2019. Disponível em: <http://portuguese. xinhuanet.com/2019-11/12/c_138548369.htm>. 
YIWEI, W. The Belt and Road Initiative: what will China offer the world in its rise. Beijing: New World Press, 2016.

YU, L. China's strategic partnership with Latin America: a fulcrum in China's rise. International Affairs, v. 91, n. 5, p. 1047-1068, 2015.

ZHANG, F. China as a global force. Asia and The Pacific Policy Studies, v. 3, n. 1, p. 120-128, 2015.

ZHAO, S. China's new foreign policy assertiveness: motivations and implications. Milan: ISPI, 2011. (Analysis, n. 54). 